\title{
LEGAL REGULATION AUTHORITY TO GRANT PERMITS ON THE VENTURE CAPITAL COMPANY
}

\author{
Anak Agung Ngurah Sagung Indradewi \\ Faculty of Law, University of Dwijendra Bali \\ Cambodia Street No. 17' Denpasar, Bali, Indonesia \\ E-mail: sagungindradewi@gmail.com
}

\begin{abstract}
The authority to grant permits to venture capital companies has a dualism of authority. The Financial Services Authority and the Ministry of Finance both have the authority to give licenses to venture capital companies. It can be seen that there are overlaps or conflicts of authority in this case institutional or legal institutions are authorized to give permission to venture capital companies. A norm of conflict over the authority of granting permission to venture capital companies, namely the Minister of Finance Regulation No. 18 / PMK.010 / 2012 concerning Venture Capital Companies (VCC) in Article 11 paragraph (1) VCCs are established in the form of limited liability companies or cooperatives, Article 12 paragraph (1) Legal entities as referred to Article 11 paragraph (1) the which carry out activities as VCC must first obtain a business permit from the Minister. Whereas the Financial Services Authority (FSA) Regulation No. 34 / POJK.05 / 2015 Concerning Business Licensing and Institutional Venture Capital Companies, in article 3 Paragraph (1) Every party conducting business activities for VCC or Sharia VCC must obtain a business license from the FSA. On the one hand the Ministry of Finance has the authority to issue a Venture Capital Company permit, but on the other hand the Financial Services Authority is also authorized to issue a Venture Capital Company permit. It is understandable that the position of state institutions and / or institutions of the Ministry of Finance with the Financial Services Authority is equal, in this case the same law was born, namely Law Number 39 of 2008 concerning the State Ministry and Law No. 21 of 2011 concerning Institutions Financial Services Authority.
\end{abstract}

Keywords: Legal Institution; Authority; Permit; Venture Capital Company

\section{A. INTRODUCTION}

The investment law term is derived from English translation. In the legislation, it can't be found investment term. To know the legal definition of investment, we must seek the views of various experts and legal dictionary. Ida Bagus Wyasa Putra said about the legal definition of investment. The investment law is legal norms regarding the possibilities to do investment, 
the terms of the investment, protection, and most importantly directed that investment can achieve prosperity for the people. ${ }^{1}$

In the community, the investment word is a term known in the daily business activities as well as in law. The investment term is a popular term in the business world, while capital investment term commonly used in the legislation. But both terms basically have the same meaning. ${ }^{2}$

Law No. 25 of 2007 on Investment has already sharply distinguish between direct investment and indirect investment. It can be seen in the explanation of Article 2 of the law, when it said "an investment in all sectors in the Republic of Indonesia is a direct capital investment and does not include indirect investment."

One that regulated in the investment law is the relationship between the investor and the recipient of capital. Investor status can be classified into two types, namely foreign investors and domestic investors. Foreign investors are investors who come from abroad, while domestic investors are investors who come from the country. Business field is a field of activity that is allowed or permitted to invest. The procedure and the terms must be met by investors to invest. The state is a state that become the place of the investment. Usually, countries that receive investments are among the countries that are developing. ${ }^{3}$ Whereas in investing in Indonesia is certainly the existence of an institution that has the authority to supervise, in this case that the Finance Services Authority (FSA).

An institute charged with supervising financial institutions, banks or non-banks, one of them in an investment, the institute called the Financial Services Authority. Law No. 21 of 2011 concerning the Institute of Financial Services Authority (FSA) is the FSA juridical basis, in this case the independent institute tasked to regulate and supervise financial institutions, banks and non-banks.

By the operation of the Institution, since the republic was existed, firstly born new Financial Services Authority (FSA) Institution, which integrated supervises institutions, namely financial institutions, banks and non-banks. The independent institution will take over the supervision of financial institutions, banks and non-banks that had been conducted by Bank Indonesia as a bank supervisor. Financial Services Authority (FSA) Institution in this case also oversees and authorizes financial institution operating in the form of venture capital companies. Regulation of the Finance Services Authority No. 34 / POJK.05 / 2015 about Business Licensing and Institutional Venture Capital Company (VCC), in Article 3 Paragraph (1) Any person conducting VCC business or Sharia VCC must obtain a license from the FSA.

Venture capital is investment as budgeting in the form capital participation into a private company as an investee company for a certain period of time. ${ }^{4}$ According to Neil Cross, the

\footnotetext{
${ }^{1}$ Salim HS and Budi Sutrisno, Hukum Investasi di Indonesia, (Jakarta: Rajawali Press, 2008), p. 9.

${ }^{2}$ Ida Bagus Rachmdi Supancana, Kerangka Hukum dan Kebijakan Investasi Langsung di Indonesia (Jakarta: Ghalia Indonesia, 2006), p. 1.

${ }^{3}$ Salim HS and Budi Sutrisno, Op.Cit., P. 21.

${ }^{4}$ Wikipedia, Venture Capital, 2019.
} 
definition of venture capital financing is a risky budgeting, usually done in the form of capital participation to companies that have the high potential start-ups development. According to Munir Fuady, venture capital is a financing by the investor in the form of capital participation in a company for a specific period, and after that period passes, the investor will be divested shares.

Regulation regarding venture capital specifically regulated in Presidential Regulation No. 9 of 2009 about Financing Institution and Ministry of Finance Regulation No. 18 / PMK.010 / 2012 about Venture Capital Company. Both of these rules describe the limitations that are general or specific about venture capital business activity and the organization. In the Presidential Regulation No. 9 In 2009, it was mentioned that the Venture Capital Company (VCC) to do business with the means of financing / capital participation in a company that receives financial aid (investee company) for a certain period of time. Financing / investments in the capital, held in shares of stock, the investment through convertible obligations and / or financing based on the results of operations division. Minister of Finance Regulation No. 18 / PMK.010 / 2012 about Venture Capital Company in Article 11 paragraph (1) VCC is established in the form of a limited liability corporation or a cooperative, Article 12 paragraph (1) The legal entity as referred to in Article 11 paragraph (1) that carries out activity as a VCC must first obtain a business license from the Minister.

Regarding its shape, fund / venture capital companies should be limited liability or a cooperative. ${ }^{5}$ That's because the financing is done by VCC form of shares of stock, where it is the provision of a limited liability company. While the form of cooperatives, constituted by one of the objectives of the VCC is to facilitate access to funds and the welfare of those who have a passion / business potential, but does not have capital.

From the description above related licensing venture capital company, it can be seen an overlap or conflict of authority in this case which institution or institutions where legal institutions authorized to issue permits venture capital firms. Conflict norms in the authority granting the venture capital firms in the Ministry of Finance Regulation No. 18 / PMK.010 / 2012 Venture Capital in Article 11 (1) VCC established as a limited liability company or a cooperative, Article 12 paragraph (1) The legal entity referred to in Article 11 (1) conducting a VCC must first obtain a license from the Minister. While Regulation of the Finance Services Authority No. 34 / POJK.05 / 2015 About Business Licensing and Institutional Venture Capital Company, in Article 3 Paragraph (1) Any person conducting business, VCC or Sharia VCC must obtain a license from the FSA.

On one side of the Ministry of Finance is authorized to issue the permit Venture Capital firms but on the other hand the Financial Services Authority also is authorized to issue licenses Venture Capital Company. It is understood that the position of state agencies or institutions and the Ministry of Finance with the Financial Services Authority is the

${ }^{5}$ Article 6 of Presidential Decree No. 9 of 2009 on Financing Institution jo. Article 11 Regulation of the Minister of Finance No. 18 / PMK.010 / 2012 Venture Capital Company. 
equivalent, in this case equally born of the Act, namelyLaw No. 39 of 2008 on the Ministry of State and Act No. 21 of 2011 of the Institute of Financial Services Authority (FSA). Based on the description above, the writer in this study took the title of the authority to grant licenses Legal Institution In Venture Capital Company.

\section{B. PROBLEM}

Based on the background of the problems that have been described, a formulation of the problem can be formulated is about how the authority to grant permission on venture capital firms?

\section{RESEARCH METHODS}

This study uses the type of normative legal research including reviewing and analyzing materials and legal Issues Issues-based legislation. This study was done to solve the legal issues that arise while the results that will be achieved is a prescription of what should be done. ${ }^{6}$ In this case the authority granting research on venture capital firms. The approach used in this study using several techniques as follows:

\section{Statute Approach}

That by using legislation and regulations approach. Legal research in dogmatic level law can not escape the law because the approach of topics that in the study came from the legislation. Approach legislation done by examining all laws and regulations relevant to the licensing authority on venture capital firms. To learn is there consistency and compatibility between a law with other laws, or the laws of the constitution or of regulation by law.

2. Conceptual Approach, namely:

That approach which moved from the views and doctrines, developed in the jurisprudence, to find ideas that gave birth to notions of law and the principles of law or legal arguments that the backrest researchers to construct legal arguments in resolving the issue of faced. ${ }^{7}$ This conceptual approach is used to find the views and doctrines developed in the jurisprudence, the study of legal principles relating to the licensing authority on venture capital firms.

\footnotetext{
${ }^{6}$ Peter Mahmud Marzuki, 2005, legal research, Prenada Media, Jakarta, p 7.

${ }^{7}$ Ibid, p .95.
} 


\section{RESULT AND DISCUSSION}

\section{The authority granting the venture capital company.}

The Ministry of Finance with the Financial Services Authority in the context of venture capital firms with regard to the investment business. Term investments or investments are terms that are known, both in daily business activities as well as in statute. The term investment is a term that is more popular in the business world, while the term investment is more widely used in the language of your invitation legislation. Investment comes from the word meaning plant invest, invest or invest money. ${ }^{8}$ So broadly similar in terms of its legal institutions. The term legal institutions Institution or institutions that are norms or rules regarding an special community activity. Norms / rules in the institution are written form (constitution, legislation applicable, appropriate penalties official law applicable) and unwritten (customs applicable). ${ }^{9}$

Article 1 of Law No. 25 of 2007 on Investment, said that the investment is all forms of capital investment activity by both domestic investment and foreign direct investment to do business in the territory of the Republic of Indonesia.

Act No. 25 of 2007 on Investment is already sharply distinguish between direct investment and indirect investment. It can be seen in the explanation of Article 2 of the law, when he says "is an investment in all sectors in the Republic of Indonesia is a direct capital investment and does not include capital investment indirectly." In this regard one venture capital company,

An agency charged with supervising financial institutions, both banks and non-bank one of them in an investment, the agency called the Financial Services Authority. Act No. 21 of 2011 of the Institute of Financial Services Authority (FSA) is the juridical basis FSA, in this case the independent body tasked to regulate and supervise financial institutions and non-bank banks. Institutions Financial Services Authority (FSA) in this case also oversees and authorizes financing institution operating in the form of a venture capital company that is on Regulation of the Finance Services Authority No. 34 / POJK.05 / 2015 About Business Licensing and Institutional Venture Capital Company.

Arrangements regarding venture capital specifically regulated in Presidential Regulation No. 9 of 2009 on Financing Agency and Ministry of Finance Regulation No. 18 / PMK.010 / 2012 Venture Capital Company. Both of these rules describe the limitations that are general or specific about venture capital and organization business activity. In the Presidential Regulation No. 9 In 2009, it was mentioned that the Venture Capital Company (VCC) to do

166.

${ }^{8}$ Andreas Halim, Complete Dictionary of 1 billion English-Indonesia (Surabaya; sulita Jaya, 2003), p.

${ }^{9}$ Wikipedia, Dictionary of Law, Legal Institution, 2019 
business with the means of financing / equity in a company that receives financial assistance (investee company) for a certain period of time. Financing / investments in the capital, held in shares of stock, the investment through convertible bonds and / or financing based on the results of operations division.

The authority granting the venture capital firms there is a dualism of authority. Institutions Financial Services Authority and the Ministry of Finance both have the authority to grant permission to the venture capital company.

Institutions Financial Services Authority (FSA), which oversees an integrated institution, namely financial institutions and non-bank banks. The independent agency will take over the supervision of banks and non-financial institutions that had been conducted by Bank Indonesia as a bank supervisor. Institutions Financial Services Authority (FSA) in this case also oversees and authorizes financing institution operating in the form of venture capital companies. Regulation of the Finance Services Authority No. 34 / POJK.05 / 2015 About Business Licensing and Institutional Venture Capital Company, in Article 3 Paragraph (1) Any person conducting business VCC or Sharia VCC must obtain a license from the FSA.

Arrangements regarding venture capital specifically regulated in the Regulation of the Minister of Finance No. 18 / PMK.010 / 2012 Venture Capital Company. The rule describes the limitations that are general or specific about venture capital and organization business activity. Minister of Finance Regulation No. 18 / PMK.010 / 2012 Venture Capital in Article 11 (1) VCC established as a limited liability company or a cooperative, Article 12 paragraph (1) The legal entity referred to in Article 11 (1) conducting a VCC must first obtain a license from the Minister.

From the description above related licensing venture capital company, it can be seen an overlap or conflict of authority in this case which institution or institutions where legal institutions authorized to issue permits venture capital firms. Conflict norms in the authority granting the venture capital firms in the Ministry of Finance Regulation No. 18 / PMK.010 / 2012 Venture Capital in Article 11 (1) VCC established as a limited liability company or a cooperative, Article 12 paragraph (1) The legal entity referred to in Article 11 (1) conducting a VCC must first obtain a license from the Minister. While Regulation of the Finance Services Authority No. 34 / POJK.05 / 2015 About Business Licensing and Institutional Venture Capital Company, in Article 3 Paragraph (1) Any person conducting business VCC or Sharia VCC must obtain a license from the FSA.

On one side of the Ministry of Finance is authorized to issue the permit Venture Capital firms but on the other hand the Financial Services Authority also is authorized to issue licenses Venture Capital Company. It is understood that the position of state agencies or institutions and the Ministry of Finance with the Financial Services Authority is the equivalent, in this case equally born of the Act, namelyLaw No. 39 of 2008 on the Ministry of State and Act No. 21 of 2011 of the Institute of Financial Services Authority (FSA). 
To answer and analyze which agency authorized to give permission Venture Capital firms, it can be analyzed using the theory, principles, and expert opinion to formulate where the competent institution.

The theory of authority used by researchers to analyze which agency the authority to give permission Venture Capital between Institutions Financial Services Authority and the Ministry of Finance. In theory the authority explained thatterm authority aligned with bevoegheid in Dutch terms, that the "authority of at least has three components, namely the influence, the legal basis and conformity law". ${ }^{4}$ Influence in this case shall have the absolute authority of influence, in the context of licensing Venture Capital Company, the Financial Services Authority has special authority on financial institutions while the Public Ministry is still common. In terms of the legal basis and the Financial Services Authority conformity law refer to lex spcialis / special in a juridical basis, namely Act No. 21 of 2011 of the Institute of Financial Services Authority (FSA).

Components of influence, that the use of authority is meant to control the behavior of legal subjects; legal basis meant that the authorities must have a legal basis whereas law conformity components meant that the authority shall have a standard.

The authority theoretically can be obtained through three ways, namely attribution, delegation, and mandates. Attribution is the provision of government authority by the legislature to the organs of government; Delegation is the delegation of authority of the government of a government organ to another organ of government; whereas the mandate occurs when the organ to allow government authorities run by other organs in her name. ${ }^{5}$ That is precisely what powers are inherent therein legal power of 3 (three) elements, which influence has exclusive categories shall be observed by others and or officials as well as office or other institution, the basic elements of the law and the elements conformity. ${ }^{6}$ That means obtaining authority, namely through:

Principle of Lex Posterior Derogat Legi Priori in this case in line with the theory of Hans Kelsen, is namely the theory of law degree (Stufentheorie) and norms degree in relation to the country. Hans Nawiasky said a legal norm of any country is always layered and tiered. ${ }^{10}$

In the Theory of Legal Reasoning (Legal Reasoning Theorie), according to Berman, the hallmark of legal reasoning is to achieve consistency in the rules of law ${ }^{11}$, As his case on The principle of Lex posterior derogat legi Priori ie the equivalent regulations, new regulations the most crippling the old regulation. So the rules have been replaced with new rules, automatically with this principle that the old rules no longer apply, ${ }^{12}$ Based on the principle of

${ }^{10}$ Farida Indrati Soeprapto, 2010, Science Legislation: Types, Functions, and Material Content, Canisius, Yogyakarta, p. 41.

${ }^{11}$ B. Arief Shidarta, 2000, Reflections About the Structure of Legal Studies A study of philosophical cornerstone and the Scientific Nature of Legal Studies Legal Studies In Development Platform Nasional Indonesia, Mandar Maju, Bandung, 2000, p. 166-167.

${ }^{12}$ Sudikno Mertokusumo 2002, Know Law (An Introduction), Molds Third, Liberty, Yogyakarta, p. 85 87. 
the Regulation of the Finance Services Authority No. 34 / POJK.05 / 2015 is a new regulation while Minister of Finance Regulation No. 18 / PMK.010 / 2012 is an old rule.

Fitriadi Mireza according to expert opinion, in accordance with the mandate of the transitional provisions of Law No. 21 of 2011 on the FSA, since December 31, 2012, the functions, duties, and authority to regulate and control activities in the financial services sector switch Financing Agency of the Ministry of Finance to the FSA. Nevertheless, they follow the technical supervision of the ministerial regulation. Supervision of the venture capital company is divided into three phases: pre-operational business, current business operations, and post business operations. ${ }^{13}$ Fitriadi Mireza of opinion is understandable that shift in the authority of the Ministry of Finance to the Financial Services Authority in this case the functions, duties, and authority of regulation and supervision in the financial services sector activities Financing Institution. These financial institutions one of them is a venture capital company.

From the description above analysis, in principle, the Financial Services Authority authorized specifically on granting permission on a venture capital company. This is the essence of that the transition of authority from the Ministry of Finance to the Financial Services Authority in this case the functions, duties, and authority to regulate and control activities in the financial services sector Financing Institutions that one of them is a venture capital company.

\section{E. CONCLUSION}

The authority granting the venture capital company in this case the Financial Services Authority has special authority on financial institutions while the Public Ministry is still common. In terms of the legal basis and the Financial Services Authority law conformity refer to lex specialis / special in a juridical basis that is Act No. 21 of 2011 of the Institute of Financial Services Authority (FSA). On The principle of Lex posterior derogat legi Prioriie the equivalent regulations, new regulations the most crippling the old regulation. So the rules have been replaced with new rules, automatically with this principle that the old rules no longer apply, Based on the principle of the Regulation of the Finance Services Authority No. 34 / POJK.05 / 2015 is a new regulation while Minister of Finance Regulation No. 18 / PMK.010 / 2012 is an old rule. In principle, the Financial Services Authority specifically authorized the granting of licenses in venture capital firms. This reality is that the transition of authority from the Ministry of Finance to the Financial Services Authority in accordance with the mandate of the transitional provisions of Law No. 21 of 2011 on the FSA in this case the functions, duties, and authority to regulate and control activities in the financial services sector Financing Institutions that one of them is a venture capital company. Suggested in the

${ }^{13}$ Mireza Fitriadi, 2014, the Legal Status of Foreign Venture Capital in Financing options Directly in Indonesia, Faculty of Law, Gadjah Mada University, Yogyakarta, p. 25. 
future in perspective legislative and executive Ius Constituendum create a Special Statute regulating Venture Capital Company which is regulated under a separate Act.

\section{REFERENCES}

Andreas Halim, Complete Dictionary of 1 billion English-Indonesia, Sulita Jaya, Surabaya; 2003.

Atmaja, Inter Authority Law (Concepts and Remedies), FH-Unud paper, Denpasar; 2013.

B. Arief Shidarta, Reflections About the Structure of Legal Studies A study of philosophical cornerstone and the Scientific Nature of Legal Studies Legal Studies In Development Platform Nasional Indonesia, Mandar Maju, Bandung in 2000.

Bagir Manan, Basics Administration System Indonesia by 1945, Padjadjaran University, Bandung: 1995.

Farida Indrati Soeprapto, Science Legislation: Types, Functions, and Material Content, Kanisius, Yogyakarta: 2010.

Ida Bagus Rachmdi Supancana, Legal and Policy Framework for Direct Investment in Indonesia, Ghalia Indonesia, Jakarta: 2006.

Law Number 21 of 2011 of the Institute of Financial Services Authority (FSA).

Law Number 25 of 2007 on Investment.

Law Number 39 of 2008 on the Ministry of State.

Minister of Finance Regulation No. 18 / PMK.010 / 2012 Venture Capital Company.

Mireza Fitriadi, Legal Status of Foreign Venture Capital in Financing options Directly in Indonesia, Faculty of Law, University of Gadjah Mada, Yogyakarta: 2014.

Peter Mahmud Marzuki, Legal Research, Prenada Media, Jakarta: 2005.

Philip M. Hadjon, the State Administrative Court, Challenge Early in Early Application of Law No. 5 of 1986, FH Magazine Airlangga, No.2-3 Year VI, Surabaya, 1990.

Presidential Decree No. 9 of 2009 on Financing Institutions.

Regulation of the Finance Services Authority No. 34 / POJK.05 / 2015 About Business Licensing and Institutional Venture Capital Company,

Ridwan, HR., The State Administration Law, UII-Press, Yogyakarta: 2000.

Salim HS and Budi Sutrisno, Investment Law in Indonesia, Eagle Press, Jakarta: 2008.

Sudikno Mertokusumo, Know Law (An Introduction), Third Edition, Liberty, Yogyakarta: 2002. 